\title{
Courts' views on climate change inundation risks for developments: Australian perspectives and considerations for valuers
}

\author{
Lucy Cradduck, Georgia Warren-Myers and Bianca Stringer
}

\begin{abstract}
Purpose: This research provides a development of the courts' views of climate change risk in planning matters as related to inundation; and suggests valuers, and others involved, need to be aware of the implications these views have on property matters and valuation processes and reporting.
\end{abstract}

Design/methodology/approach: This research engages in a legal doctrinal analysis of primary law sources, being Australian case law. It analyses decisions from Queensland, New South Wales, and Victorian courts and tribunals, to establish their views of climate change risk for coastal area developments, who bears the risk and responsibility, and if risk is shared.

Findings: The analysis reflects that developers bear the onus of proving their proposal meets relevant planning requirements including management and mitigation of climate change risks. However, the risk of developing in 'at risk' areas is a shared burden, as local government authorities remain responsible for appropriately assessing applications against those requirements.

Research limitations/implications: This research had several limitations, these included: only matters with a final determination were able to be reviewed and analysed; there is no one Australia-wide planning regime; state laws and policies are different and changing; and disputes are heard in different courts or tribunals, which can impact the weight and importance given to issues and the consistency of approaches.

Practical implications: This research informs valuers of climate change risk issues related to the inundation of new, and re-, developments, and the importance of court decisions as an additional information consideration to inform their valuations.

Originality/value: This paper is significant: it provides an understanding of the Australian courts' current views on climate change risk, and by extension the implications and considerations for valuations.

Key words climate change, coastal areas, sea level rise, valuation, risk, flood, Australia 


\section{Introduction}

Climate change has detrimental and significant impacts for property, with adverse effects experienced through increased extreme weather events, severe temperature durations and sea level rise (Warren-Myers, 2016; Bienert, 2016; IPCC 2014). While climate change impacts generally will have incremental although significant effects; the expectation of an increase in climate change risk to property from increased flood and storm events, droughts, fire events, and sea level rise are immediate and estimated to cost billions of dollars (Burgess and Rapoport, 2019). Development in areas that may be vulnerable to these risks therefore must be managed and or, preferably, avoided. An evolving area of concern is the issue of which party bears the risk. In particular, whether that risk is, or should be, shared and with whom; and whether this includes the necessity to consider governments' responsibility for those risks (Bell and Baker-Jones, 2014) requires specific attention. That climate change is a significant issue internationally is reinforced by the UK Court of Appeal's recent observation that the "issue of climate change is a matter of profound national and international importance of great concern to the public - and, indeed, to the Government of the United Kingdom and many other national governments, as is demonstrated by their commitment to the Paris Agreement" (Heathrow 2, 2020, [277]).

In a valuation context identifying risks, and whether those risks are proposed to be managed in an appropriate way, may need to be considered in valuation procedures and in the assessment and reporting of market values. Almost three decades ago Fisher and Hanemann (1993) first engaged in examining climate change risk in valuation and, more recently, empirical analysis of housing markets finds value implications for risks, such as flood and fire, can and have been realised. However, and significantly, there is a lack of the consideration of the future impact of such risks on property values (Baldauf et al., 2020).

In Australia the provision of valuations is governed by the International Valuation Standards, and the Australian and New Zealand Valuation and Property Standards, which require identification and description "of any significant observable, visual and/or known defects of hazards, e.g. flooding, landslip, observable or known site contamination, inadequate drainage etc" (APINZ, 2019, 4.11). If valuers have concerns, they should make all appropriate enquiries. This includes: referring to or specifying expert reports, other publicly or privately available information, and the client for more information, prior to proceeding with the valuation; and recording in the valuation report that this has been done. A failure to engage with all available resources and information in order to appropriately inform themselves prior to delivering their report may result in liability issues arising at a later time (Cradduck, 2016).

Issues of particular concern due to climate change arise primarily from the risk of sea level rise, flooding, land loss and salination of property (Cradduck and Teale, 2014). Other natural disasters of equal, if not more immediate, impact includes inland landslides from heavy rain, and, separately, bush fires. Risk identification and assessment therefore needs to be detailed and extensive (Cradduck, 2014). Climate change issues, however, can cause additional challenges for valuers in comparison with other more easily identifiable risks. This is because there is a lack of clarity regarding risk identification, data and information, and management; which is further exacerbated by the limited available guidance for valuers as to how such risks should be managed in the context of a valuation and its effect on value, if any. One public source for how such risks should be considered and addressed are court decisions of planning applications, as relates both to success or otherwise of an application and any conditions imposed in the approval process. 
This paper considers Australian courts' views on climate change by concentrating on the issue of concerns arising from water risks in coastal areas from future inundation as a result of sea level rise, or increased precipitation. This paper commences by engaging with current literature followed by presenting the methodology used. This research focuses on the east coast of Australia, examining decisions of the courts and tribunals from Queensland, New South Wales, and Victoria in order to ascertain their perspectives to climate changes risk, and which party bears that risk. In its analysis, and its subsequent discussion of the matters considered by that analysis, this paper considers the implications of the research for valuers and by extension financiers, owners, investors and occupiers.

\section{Literature Review}

Climate change and its effects will have various implications for property, however, the effects on property values is at present uncertain and unknown. The threat to property suggests new and clear requirements and approaches to land-use regulation are needed, as the lack of clear approaches continues to present a dilemma to many (Byrne, 2012). However, the current Australian approaches in the form of coastal management policies and planning laws that are being interpreted by the courts, which generate case law that will be utilised into the future (O'Donnell, 2016), are leading to a range of perspectives.

Extant research examining property value implications from events suggests there will be short-term value discounts due to one-off events and further potential for value to be eroded as a result of repeated events; with repetition detrimentally affecting a property's long-term value (Fuerst and Warren-Myers, 2019; Eves and Wilkinson, 2014; Lamond, 2009; Bell and Oliveras, 2006; Bin and Polasky, 2004; Eves: 2004a, 2004b, 2002; Williams and Cary, 2002; Shultz and Fridgen, 2002; Kellert and Wilson, 1993; Fibbens, 1992; Lambley and Cordery, 1991; Bialaszewski, 1990). While future risks are not necessarily considered or factored into property values (Baldauf et al., 2020), the implications of planning tools or land-use regulations do have an implication on values, as demonstrated in Beltrán et al.'s (2018) examination of flood plain affected property. The evidence presented by Walsh et al. (2019) and Bernstein (2019) also suggest sea level rise threats and protection measures are affecting property values, however, while many climate risks are considered as future risks, the implications for present values will be as a result of clear messaging through current land-use planning regulation, insurance premiums and or actual events that highlight vulnerability.

Climate change issues are recognised as matters of "exceptional public interest" (Heathrow 2, 2020, [277]) and addressing climate change will require unique solutions. In the Heathrow cases, the UK Court of Appeal was required to consider various issues arising regarding the proposed expansion of London's Heathrow airport by the construction of a third runway (Heathrow 1, 2020; Heathrow, 2). In particular, as relevant to this research, the Court of Appeal was required to consider the impact of climate change issues and the United Kingdom's commitments in that regard (Heathrow 2, 2020, [13], [17], [19], [23], [27]). In doing so, the Court of Appeal reinforced that all procedural elements as set out in planning and other relevant laws must be complied with strictly: specifically, all relevant information and or other documents required to be included within (or with) applications, or which are required to be taken into consideration in the decision making process, must be so included or considered. It is necessary therefore to first understand relevant obligations (for example see (Heathrow 2, 2020, [38], [42], [84]-[86]) and then comply with those obligations. 
As articulated by the Court of Appeal, where relevant information or documents are not included or appropriately considered this can result in a decision being legally, and fatally, flawed (Heathrow 2, 2020, [227], [233]). While the effect of this lack of materials was to make the designation decision of ANPA unlawful, and not to prohibit the third runaway per se (Heathrow 2, 2020, [280]), it serves to highlight the proscriptive requirement of planning processes and the need to engage with relevant information and materials. The decisions also serve to highlight that the public's greater awareness of climate change concerns is one that is relevant to any development application, and therefore are matters that need to be taken into consideration by developers and their advisors specifically, and, it is suggested, by relevant decision makers and governments more generally. This is particularly so when any regime enables members of the public to make submissions or objections about proposed developments. The changing landscape of climate change implications, policies and planning laws and regulations and their application will have fundamental effects on property values; and valuers, in their assessment of value, need to be aware of the evolving nature of case law and implications for property.

Proactively considering potential risks, and ensuring proposed development applications are appropriate, is of paramount concern. However, as the research reflects, information about climate risks and how this is considered in development processes is an emerging area. Many governments are yet to take action on sea level rise specifically, and there can be limited information at the local level available to developers to enable them to assess, consider and plan adaptive solutions. The lack of clarity of the issues, risks, and the parties responsible for those risks has led, and is likely to lead, to many projects being developed on land that will be subject to inundation or increased flooding in the next century. Consequently, while the developers themselves may have reduced exposure to those future risks, because information was not available and directions were not enforced through planning regimes, there is a great risk imposed on the future owners and the governments who must manage those risks. It is suggested this should influence valuation practices and reports.

\section{Methodology}

The research engaged in a doctrinal review of relevant legal and academic materials, which is an appropriate mechanism for examining laws and legal processes (Gestel \& Micklitz, 2014; Hutchinson \& Duncan, 2012). In order to identify relevant climate change issues, the research first identified and engaged with existing relevant academic research. This limited the issues for consideration to those of water risks in coastal areas.

Subsequently, in order to fulfil its purpose of informing valuers of the courts' views of developing in climate change risk areas, the research engaged in a library-based analysis of relevant case decisions (Minkkinen, 2017; van Hoecke, 2011; Hutchinson, 2002). This enabled an identification of Australian courts' views of development in climate change risk areas, the party who bears the risk of such development, and whether the risk is shared with other parties.

In Australia's multi-jurisdictional property law context, in order to seek to understand the courts' position, it is necessary to engage with decisions from various courts and tribunals within the states and territories. Relevant cases were selected in a three-step process. Step 1 involved the identification of relevant courts and tribunals in which disputes involving development applications were resolved. Step 2 involved online searches, undertaken through the online legal search engine LexisNexis (Case Base), in order to identify cases that 
specifically considered climate change issues. In order to provide workable parameters for discussion, Step 3 involved narrowing the search parameters to cases that considered water risks for the period from 2008 to 2019. This identified 14 cases considering issues relevant to water risks in coastal areas, which were then analysed for this research.

\section{Limitations}

The research has three primary limitations:

The first: Only matters with a final determination were able to be reviewed. Until a court determination is publicly available, due to a variety of reasons, there is limited if any dispute information accessible to third parties. Therefore, while the research sought to engage with as many cases as possible for this 11-year period, despite the number of cases reviewed by the authors, the research was only able to engage with a limited number of cases specifically considering water risk issues for coastal areas.

The second: The relevant laws are state-based, and there is not one Australia-wide law that applies consistently to determine development applications (Gurran, 2011). While there are federal laws, Australian property laws are primarily state/territory-based laws, a circumstance that flows from its history as a collective of British colonies each with their own 'grant' from the British Crown (Wallace et al., 2014). In addition, there are native title rights (now mainly regulated by specific legislation) applying to non-freehold lands, however, again, each state has its own laws, as well as law relevant to federal lands (Edgeworth, 2019). Further, and noting subsequent changes to planning laws and policies in the intervening years, it important to note the laws and policies engaged with in the cases considered by this research are at a fixed point in time and may not necessarily reflect current laws and policies.

The third: Disputes are heard in different courts, which can impact the weight and importance given to issues. It is rare in any event for any matter to reach the High Court for determination or the creation of one common law principle that (may) apply throughout Australia. This is due in part to the fact that most appeals to the High Court are not 'as of right', and also the limited number of cases heard in any particular year (HCA, 2019, pp.21-23). Available data was further constrained as the cases identified by the research, in which courts had considered relevant issues under development related laws as regards to risks to coastal areas from climate change, primarily were all located in the eastern states. These included three decisions from Queensland, seven from New South Wales, and four from Victoria.

Despite these limitations, this research fills an important gap as it distils decisions from across Australia into one analysis of responses to climate change risks. As it engages with cases spaning a decade plus, it also serves to reinforce the growing importance of climate change concerns in Australia more broadly and that relevant data is continually being developed.

\section{An Australian perspective}

Australia is a single island country that operates under multiple separate, and tiered legal regimes. The related systems and laws are divided between: those badged as 'federal' law, which apply across Australia; those peculiar to the six states ${ }^{1}$ and two territories, ${ }^{2}$ which only apply within the specific state or territory; and the laws and regulations (bylaws) pertaining only to the various local government authorities ('LGA') within the states and territories (also

\footnotetext{
${ }^{1}$ These are: Queensland, New South Wales, Victoria, Tasmania, South Australia and Western Australia.

2 These are: the Australian Capital Territory and the Northern Territory.
} 
known as councils). Australia correspondingly has three levels of government and government oversight: the federal (Commonwealth) government; state/territory governments, based in the respective capital cities (which means that the Australian Capital Territory (a.k.a. 'Canberra') has both the federal and its territorial governments located within it); and the various LGAs.

At the various levels therefore, and sometimes with levels of overlap and or oversight of lower levels of government, there exists regulatory control of everyday activities. In the context of land development, while most states and territories have a state/territory wide high-level planning policy and or Act, most applications for development approvals at first instances are required to be made at the local level to the LGA under their specific regulations. Subject to the LGA's determination, and the terms imposed in any development approval, the developer may proceed with the development as approved. However, as considered in the discussion of the various cases below, often, the developer will dispute the terms imposed and in other instances seek to overturn a decision that is against the application. In these instances, any dispute is then heard within the relevant state or territory court system, by either specifically designated land courts or the 'normal' system. A consequence is to limit the easy availability of relevant information: while court and tribunal decisions are easily accessible through the use of the internet by any party; the details of, and any conditions on, applications resolved without litigation are not.

The discussion that follows focusses on recent decisions from the specific land courts of Queensland and New South Wales, and the relevant Victorian tribunal.

\section{Queensland decisions}

In Queensland, the decisions considered are those of the Queensland Planning and Environment Court ('QPEC').

In 2013 in the decision in Rainbow Shores Pty Ltd v Gympie Regional Council and Others ${ }^{3}$ the issue for the QPEC's consideration was the "extent to which the proposed development would be potentially subject to storm surge, including having regard to potential sea level rise consequent upon climate change" (Rainbow, 2013, [253]). A complicating factor in that matter was that the application was heard during a period of transition between the existing and a new planning scheme (Rainbow, 2013, [24]). More significantly, in regard to the actual climate change risk, the issue was that documents that identified the relevant risk, which was of inundation from storm surges, had not been available to the applicant prior to their making the development application (Rainbow, 2013, [358]). This lack of availability, however, did not prevent QPEC from engaging with that information or requiring the applicant to engage with it now that it was available for their consideration.

The QPEC relevantly observed:

It was submitted, on behalf of the appellant, that the recent policy of taking account of potential sea level rise of that magnitude should not be foisted upon it. While again, I understand the basis for that submission, including issues of fairness to the appellant arising by reason of the creation of documents long after the application was made, such considerations must be balanced with broader considerations. (Rainbow, 2013, [359])

\footnotetext{
3 [2013] QPEC 26.
} 


\section{In refusing the application the QPEC held:}

It would, in my view, be unwise to grant a preliminary approval, which is to set the framework for substantial development over a long period of time in this locality, without ensuring that the future development is protected from potential inundation. The appellant impliedly accepts that general proposition, since it accepts that its proposal should make allowance for the 100 year ocean surge level. Once that is accepted, it is difficult to justify ignoring the current predictions of sea level rise which affect the identification of that proportion of the site which is potentially susceptible. The [plan of development] is inadequate in its current form. (Rainbow, 2013, [360])

In other circumstances it may not have been possible to require that post-application created materials be considered. However, and importantly, the planning regime enabled, and required, that all necessary and available information was required to be considered irrespective of when it was created. Once that was done, the issue of climate change risk could not be ignored. While valuations are inherently backwards looking, and the assessment of risks are often considered in the current context, with some level of unknown for matters such as flooding, engagement with all current information is clearly required. This decision reinforces that valuers should be cognisant of all available information that may affect the property that is available as at date of their assessment, irrespective of when that information became available to their client.

Later that year, in December 2013, the QPEC handed down its decision in the matter of Stockland Development Pty Ltd $v$ Sunshine Coast Regional Council and Others. ${ }^{4}$ Similarly to Rainbow (2013), it was the former planning scheme that applied to the application and the QPEC's consideration of it (Stockland, 2013, [17]). The developer's application was for redevelopment of a former sugar cane farm (Stockland, 2013, [3], [8]-[10]). The relevant risk for that site, and the local area, was inundation from flooding due to potential sea level rise and the risk of isolation for future residents as a consequence (Stockland, 2013, [15], [87][88], [91]). The QPEC weighed the private interest of the developer against the relevant planning scheme and public interest, and as against the potential risks and whether or not the developer had satisfied its evidentiary burden that the risks could be appropriately managed (Stockland, 2013, [200]-[201]). The developer could not satisfy the Court about risk management and therefore the public interest prevailed, and the QPEC declined the application. This decision highlights the need for developers to both accept responsibility for risks and to demonstrate that what is proposed meets the requirements of the relevant planning scheme as regards to managing that risk now and into the future. In terms of valuation processes, this decision raises concerns of the level of potential discounting that should be applied, as the limitation of the highest and best use being sought by this developer was not actually achievable.

In 2015 in the matter of Duffy and Anor v Sunshine Coast Regional Council and Anor ${ }^{5}$ the QPEC was required to consider issues to coastal land arising from potential landslide risk. The matter involved an appeal from a decision by the Sunshine Coast Council to refuse an application to subdivide land on Buderim into four parcels/lots with an access easement

\footnotetext{
${ }^{4}[2013]$ QPEC 79

5 [2015] QPEC 58
} 
(Duffy, 2015, [6]). The land is located on the hillside of Buderim 'mountain', an extinct volcano, and the issue was whether, due to its steep slopes, the development could be undertaken safely (Duffy, 2015, [12]). Relevantly for this research the QPEC noted the relevant planning "scheme allows for a conclusion, at a broad level, of a policy of avoidance of such risk, rather than merely minimising it" (Duffy, 2015, [49]). In refusing the application it observed that while the proposed measures served to identify the risk, those measure did not remove that risk (Duffy, 2015, [25], [61]). As the last of the Queensland decisions reviewed, Duffy (2015) reinforces that the QPEC takes a narrow view in assessing risks, in that the public interest outweighs private interests (Duffy, 2015, [61]); and that some climate change risks cannot be mitigated and need to be avoided by not permitting the proposed development. In a valuation context, this decision highlights the need to be aware of broader issues, such as the underlying purposes of the relevant planning scheme; well as the more commonly appreciated need to actually inspect the property being valued.

\section{New South Wales decisions}

More recent decisions are those from New South Wales, which are from the New South Wales Land and Environment Court ('LEC').

In the 2015 decision in Throsby \& Anor v Pittwater Council6 the LEC considered an application for a proposed amalgamation and development of two coastal lots that had been refused by the LGA on several grounds, including due to the risk of flood (Throsby, 2015, [1], [16], [95]). Relevantly the local planning scheme objectives included the requirement "to recognise and accommodate coastal processes and climate change" (Throsby, 2015, [24]). The parties themselves were proactive in resolving the matters in dispute as, between the refusal decision and the LEC hearing, and after attending a compulsory conciliation, they had resolved several matters, which included addressing concerns regarding managing the flood risk to the proposed building. Further matters were then resolved during the hearing and ultimately the application was approved by the LEC subject to agreed 'Conditions of Consent' negotiated between the parties (Throsby, 2015, [126]). Interestingly, the final point under the Advice aspect of those conditions noted:

Even though deep foundation piling may reduce the impacts of coastal hazards on the building structure, the land adjacent to tidal waters upon which the building is constructed will continue to be impacted by coastal hazards. (Throsby, 205, Conditions of Consent, p.21, note 9)

Reinforcing that some risks can never be completely avoided as, despite the parties' agreement as to how to manage the risk, they acknowledged this did not remove the risk. That the risk was acknowledged as one that was not able to be removed is a matter that would be essential to consider for, and incorporate into, any valuation report.

In the first of two 2016 decisions, being the matter of Mercury Resources Pty Ltd $v$ Parramatta City Council, ${ }^{7}$ the LEC was required to consider a proposed development to build a mixed-use building on flood prone land (it is bisected by a creek) in a high risk area of Parramatta (Mercury, 2016, [2], [6], [7], [35]). The relevant planning scheme objectives included, inter alia, "to allow development on land that is compatible with the land's flood hazard, taking into account projected changes as a result of climate change" (Mercury, 2016, [22]). While

\footnotetext{
${ }^{6}[2015]$ NSWLEC 1471

7 [2016] NSWLEC 1094
} 
adequate flood mitigation measures for the development site itself were possible, these did not outweigh the unsustainable social (due to issues of potential isolation) and economic costs to the community that would ensue from the development (Mercury, 2016, [40][43],[112]). In refusing the application the broader public interest thus prevailed over the developer's private interest. It is suggested that risks of this nature, while not of direct impact as for the property being valued, still must be appropriately considered in the valuation process as, if the surrounding land is in fact so adversely affected from a climate change event, this may impact the amenity of the property being valued.

Later that year, in the matter of Dennes $v$ Port Macquarie-Hastings Council, ${ }^{8}$ the LEC also considered the issue of flood risk but this time in the context of a proposed replacement dwelling to be constructed on an earth mound (Dennes, 2016, [4]-[7]). The evidence presented included testimony from various persons with direct knowledge of the property and the surrounding area: past and present neighbours, the applicant and his sister, and expert engineers (Dennes, 2016, [29]-[34]). The local residents provided evidence from their own personal perspectives of the impact of past flood events and how these were managed. In its consideration of the evidence the LEC noted "[g]iven the inherent risks to life and property associated with flooding it is essential that careful consideration be given to any proposal for development on flood prone land" (Dennes, 2016, [53]). However, importantly, not all land is the same, nor are all proposed developments. In this regard the LEC accepted:

... the applicant's submissions that the circumstances of this proposal for a replacement dwelling on an established rural enterprise where the landform enables safe surveillance of changes in water levels distinguishes it from a proposal for new development on flood prone land. (Dennes, 2016, [61])

After carefully consideration, noting the agreed conditions of consent between the parties, the LEC granted approval for the replacement dwelling (Dennes, 2016, [71]). This decision serves to reinforce the individual consideration that is applied to each application, and to highlight the need to ensure the court has before it all relevant information and materials from which to make its decision. It is suggested that in such a case a consideration for a future valuer (i.e. when valuing the property after construction) would be to establish that any dwelling constructed in fact complied with the court approved development conditions.

The first of two decision by the LEC in 2017 was the matter of Liverpool City Council $v$ Timova. ${ }^{9}$ The dispute between the parties related to an extension to a dwelling, an embedded wall, and a cement rendered front fence that had already been constructed (Liverpool, 2017, [2]). The issue for the LEC's consideration was whether these could remain or whether, as those works had not received approval prior to their construction, they must be demolished (Liverpool, 2017, [4], [12]). A relevant issue for the LEC's consideration was the fact that the development was within a known flood zone and subject to planning requirements designed to keep people safe and minimise damage from flooding risk (Liverpool, 2017, [25]-[30], [42]).

In its consideration the LEC noted that the LGA had inappropriately delayed in bringing the civil action, as there was a lapse of 25 months from its first inspection to the LGA notifying the homeowner of its intention to seek demolition orders for what had been constructed. The LEC observed that this delay had resulted in the works not being stopped at an early stage to

\footnotetext{
${ }^{8}$ [2016] NSWLEC 1345

9 [2017] NSWLEC 138
} 
the disadvantage of the homeowner (Liverpool, 2017, [167]). Ultimately, the LGA was successful, however, the LEC specifically declined to make an order about costs:

The Court's discretion with respect to costs is nevertheless broad and, so, in a case where the circumstances warrant it, the Court can adopt a course at variance to the normal approach. This case is an instance where such a variance is warranted. Although Liverpool Council has succeeded, the Court in its discretion will not order the Respondents to pay the Council's costs. In this respect, I note at the outset that the position of Liverpool Council in response to the Court raising the fact that costs are sought in the Summons was: "Yes, but it's a matter for obviously your Honour in the exercise of the discretion ..." (Transcript, 14 June 2017, p 47). (Liverpool, 2017, [166])

As reflected in the LEC order, the parties agreed that the embedded wall could remain (Liverpool, 2017, [14]) but that the fence would be demolished within 90 days and the homeowner could apply to the LGA for approval to construct a more suitable fence that permitted, rather than blocked, water flow (Liverpool, 2017, [13, [170]). The LEC also ordered the extension was to be demolished within 12 months (Liverpool, 2017, [2], [170]), in doing so it observed:

When issues of human health and safety are at the core of planning and environmental controls, as is the case with floodway management controls, it can be justifiably argued that such considerations must be given paramount weight. (Liverpool, 2017, [164])

During the course of the dispute complicating issues arose in that the homeowner was a migrant with limited English. Related to this point, the LEC commented on the responsibility of other parties to the homeowner, being the selling agent and their conveyancing lawyer, specifically noting that:

The unfortunate circumstances in this case is a sad reflection of the efficacy of the administration of planning processes, which could have been avoided had timely and expeditious action occurred. I am also satisfied that, at the time of the purchase of the Land in 2009, the First Respondent and his family insufficiently understood the implications of the applicable flood mitigation controls and policies. It is trite to observe that professional selling agents and lawyers retained to handle the conveyancing associated with the purchase of land have a duty to ensure that purchasers are made aware of materially relevant controls which might limit their expectations with response to the use and development of such land. (Liverpool, 2017, [133])

While this did not prevent the orders being made, arguably the effect of such observations is to extend the risk for identifying climate change issues beyond those directly involved in the development process. The authors, however, have not be able to ascertain if the homeowner took any legal action against the agent or their solicitor. In the context of valuing such a property, the current issues of non-compliance with the planning scheme should be clearly accounted for in the valuation report. This decision, it is suggested, also highlights the need for physical inspection of any property under redevelopment and then comparison against the publically accessible planning scheme requirements and approved building plans to identify any changes since the original construction was approved. 
The second relevant 2017 decision of the LEC is the matter of Pridel Investments Pty Ltd $v$ Coffs Harbour City Council. ${ }^{10}$ This involved inter alia a consideration of risks from sea level rise and flooding to a proposed subdivision of 38-lot residential lots and one residual lot, which included a boundary adjustment (Pridel, 2017, [3], [72]). The LGA has refused the application on various grounds, including the "[u]nacceptably high risk of flooding and inundation" (Pridel, 2017, [5]). The developer was unable to satisfy the Court regarding these risks. The LEC refused the application (Pridel, 2017, [160]) and in doing so observed:

The purpose of undertaking a risk assessment is to cater for uncertainty, not to resolve it. The Applicant submits that the risk from coastal processes is so remote that it should not be considered. Yet a number of experienced experts in coastal processes, town planning, flooding and ecology have expressed serious reservations about this development which have not been satisfactorily dealt with on the evidence. [The principles of ecological sustainable development] ... (specifically, the precautionary principle) ... [within the relevant planning policy] requires more where there is a risk of serious harm or damage to the environment, life, and property. It casts an onus on the Applicant to demonstrate that those risks have been assessed, and that mitigation measures can be implemented to avoid them. (Pridel, 2017, [159])

Arguably, of all the cases reviewed, this decision provides the clearest statement regarding an appropriate approach to considering climate change risks to residents and the environment, while articulating that the responsibility for ameliorating such risks rests with the property developer. Again, this decision serves to highlight the fact that not all risks can be removed and as such appropriate comment and consideration must be included in any valuation report.

In 2019, in the matter of Gloucester Resources Limited $v$ Minister for Planning, ${ }^{11}$ the LEC made pertinent statements regarding climate change risks. Specifically, in observations made as to the appropriateness of various types of developments, the LEC noted that:

Seaside residential development can only be built at the seaside, but not every seaside development is acceptable to be approved. For example, the likely impact of coastal processes and coastal hazards on coastal development, including with climate change, may be sufficiently serious as to justify refusal of the coastal development. (Gloucester, 2019, [692])

While the matter itself was not one for which water risks were an issue, as it involved consideration of an application for approval for an open cut coal mine (Gloucester, 2019, [4]), it serves to highlight the broad engagement that the courts can take with such matters. As noted above, it is suggested that valuers should also take a broad approach to the sources with which they engage as their consider factors that may impact upon a property's value.

The more recent LEC decision from 2019, in the matter of Michael Brown Planning Strategies $v$ Wingecarribee Shire Council, ${ }^{12}$ again highlights that not all identified risks can be mitigated. This matter involved the consideration by the LEC of an application for a three-lot subdivision and construction of a 42-unit residential building (reduced after conciliation to 34 units) proposed to be developed on land located in a flood plain (Brown, 2019, [1], [4], [9]). The

\footnotetext{
${ }^{10}$ [2017] NSWLEC 1042

11 [2019] NSWLEC 7

12 [2019] NSWLEC 1311
} 
identified flood risk for the site was medium to high (Brown, 2019, [34], [35]). The LEC noted that:

... the agreed expert evidence is that, firstly the development cannot be allowed to proceed before the railway culvert augmentation works, and secondly that without the culvert augmentation works the site is unable to be developed in its present form due to the significant flood affectation constraint. Importantly, the experts do not conclude that the [creation of the proposed fill platform] ... is sufficient to render the development compatible with this flood affectation. (Brown, 2019, [72])

After considering expert reports, and witness and other evidence, the LEC refused the application and held:

Giving appropriate weight to the expert evidence I am unable to form an opinion of satisfaction that the development is capable of existing in harmony with the flood hazard of the land. Given I am unable to be satisfied that the development is compatible with the flood hazard of the land the application must be refused. (Brown, 2019, [77])

Again, merely identifying a risk, and attempting to manage for that risk is not the same as removing the risk. Public safety and other concerns take precedence over private interests for the development in at risk areas, which, again, are matters that should be included in any valuation report.

\section{Victorian decisions}

The research identified four relevant cases considering risk for coastal areas from the Victorian court system, these were all decisions of the Victorian Civil and Administrative Tribunal ('VCAT'). A more recent decision from the Victorian Supreme Court, being the matter of Gray v Minister for Energy, Environment and Climate Change, ${ }^{13}$ is not considered by this research as the relevant climate change risk in that matter was from bushfires.

The first VCAT decision considered was from 2008 in the matter of Gippsland Coastal Board $v$ South Gippsland Shire Council \& Ors (No 2). ${ }^{14}$ In that matter the Tribunal was asked to review a decision of the South Gippsland Shire Council to grant a permit for dwellings to be built on crown allotments in a coastal area (Gippsland, 2008, [1]). In reviewing that decision it was necessary for the Tribunal to engage with the Victorian State Planning Policy Framework (Gippsland, 2008, [10]), which includes inter alia the need to "identify and avoid development in areas susceptible to flooding..., landslip, erosion" (Gippsland, 2008, [22]). This need was consistent with, but not specifically addressed, in local planning requirements (Gippsland, 2008, [23]).

In their objection to the permits the Board raised two bases related to 'environmental concern': that is "[the dwellings] pose an unnecessary and unacceptable risk to the coastal environment; and [t]hey are inappropriate in light of climate change studies undertaken by the CSIRO on behalf of the Board." (Gippsland, 2008, [32]). Noting those studies were

\footnotetext{
${ }^{13}[2019]$ VSC 382

14 [2008] VCAT 1545
} 
preliminary in nature (Gippsland, 2008, [33]), and while not adopting the study findings, the Tribunal observed that:

... we have had regard to the broader picture that there is a general consensus that some level of climate change will result in extreme weather conditions beyond the historical record that planners and others rely on in assessing future potential impacts. It is, in our view, no longer sufficient to rely only on what has gone before to assess what may happen again in the context of coastal processes, sea levels or for that matter inundation from coastal or inland storm events. (Gippsland, 2008, [40])

In considering whether the risk was acceptable (it was not), the Tribunal noted:

We accept that there is growing evidence of sea level rises and risks of coastal inundation. While we acknowledge that there is uncertainty as to the magnitude of the sea level rise, it is evident that the consequences of such rises in level will be complex due to the dynamic nature of the coastal environment. Put plainly, rising sea levels are to be expected. The range of impacts may well be beyond the predictive capability of current assessment techniques. In the face of such evidence, a course of action is warranted to prevent irreversible or severe harm. (Gippsland, 2008, [42])

In determining that it was necessary to engage with "sea level rise and risk of coastal inundation" (Gippsland, 2008, [46]) the Tribunal observed the "relevance of climate change to the planning decision making process is still in an evolutionary phase. Each case concerning the possible impacts of climate change will turn on its own facts and circumstances" (Gippsland, 2008, [47]). The Tribunal then held that:

We consider that increases in the severity of storm events coupled with rising sea levels create a reasonably foreseeable risk of inundation of the subject land and the proposed dwellings, which is unacceptable. This risk strengthens our conclusion that this land and land in the Grip Road area generally is unsuitable for residential development. (Gippsland, 2008, [48])

The Tribunal also specifically engaged with risks from flooding (Gippsland, 2008, [49]-[52]) before setting aside the permits. One of their final observation was that "...the impacts that the environment may have on these dwellings are unacceptable and make the land unsuited for the proposed development" (Gippsland, 2008, [53]). Similarly to Rainbow (2013), this decision serves to highlight the need to ensure that all available information, whether in final form or draft, is considered in the valuation process and report.

In 2009 VCAT heard the matter of Owen $v$ Casey City Council. ${ }^{15}$ It was required to consider whether a coastal hazard vulnerability assessment was required prior to granting the development approval for the construction of two double storey dwellings proposed for land located in a known flood area (Owen, 2009, [2],[4]). In determining that such an assessment was required for the proposed development (Owen, 2009, [19]) the Tribunal noted that, as articulated in previous decisions, changes to State Policy had placed "a much more significant onus on both permit applicants to consider risks in design and on decision makers to take climate change into account" (Owen, 2009, [10]). It was therefore necessary that, in order that risks should be known so appropriate mitigating action can be taken, assessments such

\footnotetext{
${ }^{15}[2009]$ VCAT 1946
} 
as a coastal hazard vulnerability assessment were required even for small developments (Owen, 2009, [14]). In a valuation context, this decision serves to highlight the need to engage with all relevant documents and for valuers to have an awareness of related (non-valuation) processes, so that the valuer is cognizant of all matters that may have an impact on the property being valued.

In its 2010 decision in the matter of L Taip v East Gippsland Shire Council ${ }^{16}$ VCAT considered an application for the construction of eight multi-level dwellings across three buildings situated over two lots. This property was located in Lakes Entrance, which the Tribunal noted "is a regional town that has a very high vulnerability to flooding and to the impacts of climate change, including sea level rise" (L Taip, 2010, [8]). Further, it observed that:

... perhaps more than any other case that has come before the Tribunal to date, this matter brings into focus how the Victorian planning system seeks to deal with the pressing issues of climate change, rising sea levels and the vulnerability of coastal communities to the associated impacts of these conditions. It is the vulnerability of Lakes Entrance, and in particular the subject site, that raise concerns about this proposal at this time. (L Taip, 2010, [9])

In determining to set aside the granted approval, the Tribunal made several observations as to the rationale for its decision, most importantly that "there are two parts to this [flood] risk: The current level of risk and the future risk under climate change scenarios" (L Taip, 2010, [52]). Other observations included inter alia that "[i]t is not sufficient to rely simply on raising a building above the projected water levels expected under climate change in order to acceptably address the totality of climate change impacts" and that "[t]he purported ability of the development to achieve its economic life is not an argument that has planning merit" (L Taip, 2010, [60]).

As to the party responsible for addressing climate change risks the Tribunal held:

... the design response is insufficient in addressing these wider risks. However it would be unfair to consider that the proponents would need to address all of those risks alone or at all in some instances given that they arise from the susceptibility of infrastructure that is beyond their control. Such risks need to be addressed by the Council and other relevant authorities and / or service providers. I was presented with no evidence that these risks are being actively addressed." (L Taip, 2010, [70])

The responsibility to ensure that climate change risks can be managed by the developer, and if they can then that they are managed, rests with the decision maker and other relevant regulatory bodies. In this case that was the LGA, being the East Gippsland Shire Council. This decision identifies a matter of potentially very significant concern for valuers: if an LGA has granted a development approval, surely the valuer should be able to rely on it. However, as identified by the Tribunal, the fact was that the LGA had not themselves followed correct process in granting the original approval. It is suggested that this decision serves to reinforce the need for familiarity with relevant processes so that where it appears that regulatory documents are inadequate (or missing) appropriate notations, and disclaimers, may be made within the valuation report.

${ }^{16}[2010]$ VCAT 1222 
The final decision considered from Victoria, also from 2010, was in the matter of Cooke \& Ors $\checkmark$ Greater Geelong City Council ${ }^{17}$ regarding whether the LGA should have granted approval for construction of two two-storey attached dwellings. Similarly to Owen (2009), an issue arose regarding the need for a coastal hazard vulnerability assessment. VCAT itself raised the issue of whether an assessment should have been obtained prior to the LGA granting approval (Cooke, 2010, [59]). The Tribunal determined the assessment should have been provided and gave the developer any opportunity to obtain such an assessment before it made a final decision (Cooke, 2010, [80]). In doing so the Tribunal observed inter alia that 'low risk' as noted in the relevant reports could not be read as 'no risk', such that a risk of "increasing coastal erosion associated with climate change and sea level rise" did exist (Cooke, 2010, [75]). It was the developer's responsibility to ensure the proper assessment of risks to property in considering potential climate change effects, and the development would have no prospect of proceeding without that assessment (Cooke, 2010, [81]). This decision, again, reinforces the need to have the knowledge to be able to engage appropriately with related documents in order both to properly assess a property's value and to ensure that appropriate notations are made within the valuation report.

\section{Discussion and conclusion}

Queensland's consideration of relevant matters, as reflected for example in Stockland (2013), confirmed that it is for the developer to demonstrate the proposed development meets the relevant planning scheme's requirements and appropriately addresses all relevant risks. This too was confirmed in the LEC decisions, which also provided the best in depth discussion around climate change risks and the impact these may hold for development, albeit determining that while the developer has the obligation to meet those risks not all risks are insurmountable. This was evidenced, for example, in the decision in Throsby (2015), where related risks were overcome through agreed amendments to the building design. Pridel (2017) also reinforced that where a developer cannot demonstrate that the requirements under the planning laws and policies are met, particularly as regards to risk mitigation, then consent for the development cannot be granted. Consistently with the Queensland and New South Wales decisions, the Victorian decisions, while of a tribunal, also recognised the existence of climate change risks, and found the responsibility for managing these in the development process rests primarily with the developer. However, as considered in L Taip (2010), that responsibility, subject to planning scheme requirements, is one that can be shared with the LGA as LGAs remain responsible for appropriately assessing applications against those standards and also ensuring the right standards are set. State and territory governments, and the federal government, however, generally are removed from this process and risk.

The decisions considered are consistent in that it is the developer (or individual seeking approval for the development) who bears the primary responsibility for risks. The developer also has the onus on addressing and proving that any climate change or natural hazard risk identified is addressed and managed for in accordance with relevant legislation, LGA policies and planning schemes. In this process it appears that the consent authority (generally the LGA) shares at least in part in that risk, as it has the responsibility to appropriately apply the relevant legislation and policies in considering and assessing development applications. That is, the LGA is required to come to an appropriate decision based upon a considered

\footnotetext{
${ }^{17}[2010]$ VCAT 60
} 
assessment of all relevant factors for the proposed development under the application as submitted. Where critical information is missing, and therefore relevant issues cannot be properly considered (Owen, 2009; Cooke, 2010), it is not appropriate for the LGA to grant the development application. If an approval is not appropriately granted then, as Gippsland (2008) highlights, it will be subject to review and action by statutory bodies as well as the courts.

The research reflects that, generally, a narrow approach is adopted in Australia in assessing risk, which is one that looks to the public interest over any private interest of the developer. Most commonly, even where it can be demonstrated that a risk is able to be potentially mitigated (even at a substantial cost to the developer), if the risk is significant in terms of affecting the resident(s) and emergency services personnel who may respond, then the court/tribunal is unwilling to grant the development application. Importantly, courts and tribunals have evidenced that they are not constrained in considering relevant issues and that they will look beyond the matters raised by the parties themselves as necessary. Table 1 identifies the relevant risks for each application considered, and the lessons for valuers from the decisions:

Table 1: Case details

\begin{tabular}{|c|c|c|c|c|}
\hline Year & Court & Case & Risk/s & Lesson/s for valuers \\
\hline 2008 & VCAT & Gippsland & $\begin{array}{l}\text { Sea level rise } \\
\text { Flooding }\end{array}$ & $\begin{array}{l}\text { All necessary and available information must } \\
\text { be considered in approval process }\end{array}$ \\
\hline 2009 & VCAT & Owen & Flooding & $\begin{array}{l}\text { Process for development approval needs to } \\
\text { be followed strictly } \\
\text { All necessary and available information must } \\
\text { be considered in approval process }\end{array}$ \\
\hline 2010 & VCAT & L Taip & $\begin{array}{l}\text { Sea level rise } \\
\text { Flooding }\end{array}$ & $\begin{array}{l}\text { Process for development approval needs to } \\
\text { be followed strictly } \\
\text { All necessary and available information must } \\
\text { be considered in approval process }\end{array}$ \\
\hline 2010 & VCAT & Cooke & Coastal erosion & $\begin{array}{l}\text { Process for development approval needs to } \\
\text { be followed strictly } \\
\text { All necessary and available information must } \\
\text { be considered in approval process } \\
\text { "low risk" does not mean "no risk" }\end{array}$ \\
\hline 2013 & QPEC & Rainbow & Storm surge & $\begin{array}{l}\text { All necessary and available information must } \\
\text { be considered in approval process }\end{array}$ \\
\hline 2013 & QPEC & Stockland & $\begin{array}{l}\text { Sea level rise } \\
\text { Isolation of residents }\end{array}$ & $\begin{array}{l}\text { Need clear evidence the risks can be } \\
\text { managed into the future } \\
\text { Need to test that the claimed highest and } \\
\text { best use is achievable. }\end{array}$ \\
\hline 2015 & LEC & Throsby & Flooding & Some risks cannot be mitigated or managed \\
\hline 2015 & QPEC & Duffy & Landslide & $\begin{array}{l}\text { Public interest outweighs private interest } \\
\text { Some risks cannot be mitigated or managed } \\
\text { Highlights need for inspection }\end{array}$ \\
\hline
\end{tabular}


Also, in assessing any development application, the research reflects that Australian courts and tribunals generally conduct a weighing exercise, which involves considering all needs, benefits and risks. That weighing is undertaken subject to, and under the requirements of, the relevant laws, policies and processes specified in the relevant planning legislation and or local policies and/or frameworks. This involves weighing the need for, and benefit from, the development proceeding, as against any identified risks of the proposed development. In terms of benefits, this includes economic, community and social benefits. In terms of risks, as identified, these include the risks arising from climate change events with the identified risks of such events commonly outweighing the need/benefit for the develop such that approval is not granted.

In seeking to inform valuers of how the courts view matters of climate change risk, it is important to note that, while the cases analysed are indicative of the matters the courts and tribunals will consider, they are not the totality of the development applications made. As with any court matter, these decisions are generally reflective only of matters that are in dispute, being those for which an initial approval was not given and or where a matter could not be resolved by the developer with the LGA before an appeals deadline meant a court application had to be made. Where an application is approved, or an agreement is reached before any deadline to commence proceedings arises, those matters were beyond the scope of this research to consider as they were not accessible. Therefore, and importantly, a valuer must always seek to make their own inquiries, and to be informed about relevant policies and schemes, so that their knowledge of such matters can support their consideration of any property and proposal. Such matters also must be reflected in their valuation reports.

Importantly, as was the position in the Heathrow cases, the research also reflects that the Australians courts are required to engage with the governments' and LGAs' planning objectives as articulated in the various laws and policies. As regards coastal areas, this means it is legitimate and necessary in the development approval process to consider sea level rise and other climate change risks as both current and future risk issues, and to require 
developers to consider and present information relevant to how potential impact to developments will be appropriately managed or mitigated. The impact for valuers and valuation, and the market values of development projects and existing properties, cannot be underestimated. There are now other significant matters requiring a valuer's consideration, which they may need to identify from sources other than the developer or their client, in order to be in a position to properly complete their valuation report.

\section{Reference List}

Australian Property Institute and Property Institute of New Zealand ('APINZ') (2019), Technical Information Paper - Valuation Procedures - Real Property https://www.api.org.au/sites/default/files/uploaded-content/websitecontent/anzvtip_11_valuation_procedures_real_property_01072019.pdf

Baldauf, M., Garlappi, L. and Yannelis, C. (2020), Does climate change affect real estate prices? Only if you believe in it. The Review of Financial Studies, Vol. 33 No. 3, pp. 1256-1295.

Bell, J. and Baker-Jones, M. (2014), "Retreat from retreat - the backward evolution of sealevel rise policy in Australia, and the implications for local government", Local Government Law Journal, Vol. 19 No. 1, pp. 23-35.

Bell, T. and Oliveras, I. (2006), "Perceptions of Prescribed Burning in a Local Forest Community in Victoria, Australia", Environmental Management, Vol. 38 No. 5, pp. 867-878.

Beltrán, A., Maddison, D., and Elliott, R. (2018), Assessing the Economic Benefits of Flood Defenses: A Repeat-Sales Approach, Risk Analysis, Vol. 38, No. 11, pp.2340-2367.

Bernstein, A., Gustafson, M., and Lewis, R. (2019), “Disaster on the horizon: The price effect of sea level rise', Journal of Financial Economics, Vol. 134 No. 2, pp. 253-272.

Bialaszewski, D. (1990), "Adjusting comparable sales for floodplain location; the case of Homeworld, Alabama", The Appraisal Journal, Vol. 58 No. 1, pp. 114-118.

Bienert, S. (2016), Climate Change Implications for Real Estate Portfolio Allocation Industry perspectives, Heitman, Urban Land Institute.

Bin, O. and Polasky, S. (2004), "Effects of flood hazards on property values: Evidence before and after Hurricane Floyd", Land Economics, Vol. 80 No. 4, pp. 490-500.

Burgess, K. and Rapoport, E. (2019), Climate Risk and Real Estate Investment Decision-Making, Heitman, Urban Land Institute.

Byrne, J. (2012), "The Cathedral Engulfed: Sea-Level Rise, Property Rights, and Time", Louisiana Law Review, Vol. 73 No. 1, pp. 69-118.

Cradduck, L. (2016), "After the rains: water's impact for valuation practices", Property Management, Vol. 34 No. 2, pp. 158-174.

Cradduck, L. (2014), “'Water view' from cyberspace: building resilient communities by identifying water risks", In Bond, S (Ed.) Proceedings of the 20th Annual Pacific Rim Real Estate Society Conference. Pacific Rim Real Estate Society, New Zealand.

Cradduck, L. and Teale, J. (2014), "A sunburnt country - storms, surges and sea levels: of insurance and flooding rains", Geography Research Forum, Vol. 34 No. 1, pp. 123-141.

Edgeworth, B. (2017), Butt's Land Law, Thomson Reuters (Professional) Australia Pty Limited, Pyrmont, NSW.

Eves, C. (2002), "The long-term impact of flooding on residential property values", Property Management, Vol. 20 No. 4, pp. 214-27. 
Eves, C. (2004a), "The impact of bushfires on residential property markets", Pacific Rim Property Research Journal, Vol. 10 No. 4, pp. 413-427.

Eves, C. (2004b), "The impact of flooding on residential property buyer behaviour: an England and Australian comparison of flood affected property", Structural Survey, Vol. 22 No. 2, pp. 84-94.

Eves, C. and Wilkinson, S. (2014), Natural Hazards, Apr 2014, Vol. 71 No. 3, pp. 1519-1536.

Fibbens, M. (1992), Effect of Flooding on Residential Property Values. Property Research Centre Report. University of Western Sydney, Hawkesbury, NSW.

Fisher, A. and Hanemann, W. (1993), Assessing climate change risks: Valuation of effects. In Assessing Surprises and Nonlinearities in Greenhouse Warming: Proceedings of an Interdisciplinary Workshop. Darmstadter, J. and Toman, M. A. (Eds). Resources for the Future. Washington DC.

Fuerst, F. and Warren-Myers, G. (2019), "Sea Level Rise and House Price Capitalisation", SSRN https://ssrn.com/abstract=3359289 or http://dx.doi.org/10.2139/ssrn.3359289

Gestel, R. and Micklitz, H. (2014), Why methods matter in European legal scholarship, European Law Journal, Vol. 20 No. 3, pp. 292-316.

Gurran, N. (2011), Australian Urban Land Use Planning: Principles, Systems and Practice, $2^{\text {nd }}$ Ed, Sydney University Press, Sydney, NSW.

High Court of Australia ('HCA') (2019), Annual Report 2018-2019, 24 October 2019 https://cdn.hcourt.gov.au/assets/corporate/annual-reports/HCA_Annual_Report_201819.pdf (viewed 06.05.2020).

Hutchinson, T. (2002), Researching and Writing in Law. Lawbook Co, Australia.

Hutchinson, T., and Duncan, N. (2012), Defining and describing what we do: Doctrinal legal research, Deakin Law Review, Vol. 17 No. 1, pp.83-119.

IPCC (2014), Climate Change 2014: Synthesis Report, Contribution of Working Groups I, II and III to the Fifth Assessment Report of the Intergovernmental Panel on Climate Change [Core Writing Team, R.K. Pachauri and L.A. Meyer (Eds.)]. IPCC, Geneva, Switzerland.

Kellert, S. and Wilson, E. (1993), The biophilia hypothesis. Island Press, Washington, USA.

Lambley, D. and Cordery, I. (1991), "Effect of Floods on the Housing Market in Sydney", Conference Proceedings, International Hydrology and Water Symposium, Perth Western Australia, October 1991.

Lamond, J. (2009), Flooding and Property Value, FiBRE Series, RICS, UK.

Minkkinen, P. (2017), Critical legal 'method' as attitude, in Watkins, D and Burton, M, (Eds), Research Methods in Law, 2nd edn, Routledge, London, UK.

O'Donnell, T. (2016), "Legal geography and coastal climate change adaptation: The Vaughan litigation", Geographical Research, Vol. 54 No. 3, pp. 301-312.

Shultz, S. and Fridgen, P. (2002), "Floodplains and housing values: implications for flood mitigation projects", Journal of American Water Resources Association, Vol. 37 No. 3, pp. 595-603.

Van Hoecke, M. (2011), 'Legal Doctrine: Which Kind of Method(s) for What Kind of Discipline?', in Van Hoecke, M, (Ed) (2011) Methodologies of Legal Research: Which Kind of Method for What Kind of Discipline, Hart Publishing Ltd, Oxon, UK, pp.1-18. 
Wallace, A., McCrimmon, L. and Weir, M. (2014), Real Property Law in Queensland, Thomson Reuters (Professional) Australia Limited, Pyrmont, NSW.

Walsh, P., Griffiths, C., Guignet, D., and Klemick, H. (2019), "Adaptation, Sea Level Rise, and Property Prices in the Chesapeake Bay Watershed", Land economics, Vol. 95 No. 1, pp. 1934.

Warren-Myers, G. (2016), "Climate Change, Extreme Weather Events and Property: Risk and Resilience", Australian and New Zealand Property Journal, Vol. 5 No. 4, pp. 298- 302.

Williams, K. and Cary, J. (2002), "Landscape preferences, ecological quality, and biodiversity protection. Environment and Behavior", Vol. 34 No. 2, pp. 257-274.

\section{Cases}

Cooke \& Ors v Greater Geelong City Council [2010] VCAT 60 ('Cooke')

Dennes v Port Macquarie-Hastings Council [2016] NSWLEC 1345 ('Dennes')

Duffy and Anor v Sunshine Coast Regional Council and Anor [2015] QPEC 58 ('Duffy')

Gippsland Coastal Board v South Gippsland Shire Council \& Ors (No 2) [2008] VCAT 1545 ('Gippsland')

Gloucester Resources Limited v Minister for Planning [2019] NSWLEC 7 ('Gloucester')

Gray v Minister for Energy, Environment and Climate Change [2019] VSC 382

L Taip v East Gippsland Shire Council [2010] VCAT 1222 ('L Taip’)

Liverpool City Council v Timova [2017] NSWLEC 138 ('Liverpool')

Mercury Resources Pty Ltd v Parramatta City Council [2016] NSWLEC 1094 ('Mercury')

Michael Brown Planning Strategies v Wingecarribee Shire Council [2019] NSWLEC 1311 ('Brown')

Owen v Casey City Council [2009] VCAT 1946 ('Owen')

Pridel Investments Pty Ltd v Coffs Harbour City Council [2017] NSWLEC 1042 ('Pridel')

Rainbow Shores Pty Ltd v Gympie Regional Council and Others [2013] QPEC 26 ('Rainbow')

The Queen (on the application of (1) Heathrow Hub Limited (2) Runaway Innovations Limited) $v$ Secretary of State for Transport and others [2020] EWCA Civ 213 ('Heathrow 1')

The Queen (on the application of Friends of the Earth) $v$ Secretary of State for Transport and others [2020] EWCA Civ 214 ('Heathrow 2')

Stockland Development Pty Ltd v Sunshine Coast Regional Council and Others [2013] QPEC 79 ('Stockland')

Throsby \& Anor v Pittwater Council [2015] NSWLEC 1471 ('Throsby') 
Table I: Case details

\begin{tabular}{|c|c|c|c|c|}
\hline Year & Court & Case & Risk/s & Lesson/s for valuers \\
\hline 2008 & VCAT & Gippsland & $\begin{array}{l}\text { Sea level rise } \\
\text { Flooding }\end{array}$ & $\begin{array}{l}\text { All necessary and available information must } \\
\text { be considered in approval process }\end{array}$ \\
\hline 2009 & VCAT & Owen & Flooding & $\begin{array}{l}\text { Process for development approval needs to } \\
\text { be followed strictly } \\
\text { All necessary and available information must } \\
\text { be considered in approval process }\end{array}$ \\
\hline 2010 & VCAT & L Taip & $\begin{array}{l}\text { Sea level rise } \\
\text { Flooding }\end{array}$ & $\begin{array}{l}\text { Process for development approval needs to } \\
\text { be followed strictly } \\
\text { All necessary and available information must } \\
\text { be considered in approval process }\end{array}$ \\
\hline 2010 & VCAT & Cooke & Coastal erosion & $\begin{array}{l}\text { Process for development approval needs to } \\
\text { be followed strictly } \\
\text { All necessary and available information must } \\
\text { be considered in approval process } \\
\text { "low risk" does not mean "no risk" }\end{array}$ \\
\hline 2013 & QPEC & Rainbow & Storm surge & $\begin{array}{l}\text { All necessary and available information must } \\
\text { be considered in approval process }\end{array}$ \\
\hline 2013 & QPEC & Stockland & $\begin{array}{l}\text { Sea level rise } \\
\text { Isolation of residents }\end{array}$ & $\begin{array}{l}\text { Need clear evidence the risks can be } \\
\text { managed into the future } \\
\text { Need to test that the claimed highest and } \\
\text { best use is achievable. }\end{array}$ \\
\hline 2015 & LEC & Throsby & Flooding & Some risks cannot be mitigated or managed \\
\hline 2015 & QPEC & Duffy & Landslide & $\begin{array}{l}\text { Public interest outweighs private interest } \\
\text { Some risks cannot be mitigated or managed } \\
\text { Highlights need for inspection }\end{array}$ \\
\hline 2016 & LEC & Mercury & $\begin{array}{l}\text { Flooding } \\
\text { Isolation of residents } \\
\text { Economic impacts to } \\
\text { community }\end{array}$ & Public interest outweighs private interest \\
\hline 2016 & LEC & Dennes & Flooding & $\begin{array}{l}\text { All necessary and available information must } \\
\text { be considered in approval process } \\
\text { Need to check future construction in fact } \\
\text { complies with development conditions }\end{array}$ \\
\hline 2017 & LEC & Liverpool & Flooding & $\begin{array}{l}\text { Process for development approval needs to } \\
\text { be followed strictly } \\
\text { Need to check future construction in fact } \\
\text { complies with development conditions }\end{array}$ \\
\hline 2017 & LEC & Pridel & $\begin{array}{l}\text { Sea level rise } \\
\text { Flooding }\end{array}$ & Some risks cannot be mitigated or managed \\
\hline 2019 & LEC & Gloucester & $\mathrm{n} / \mathrm{a}$ & Some risks cannot be mitigated or managed \\
\hline 2019 & LEC & Brown & Flooding & Some risks cannot be mitigated or managed \\
\hline
\end{tabular}




\section{University Library}

\section{- M M I N E R VA A gateway to Melbourne's research publications}

Minerva Access is the Institutional Repository of The University of Melbourne

Author/s:

Cradduck, L;Warren-Myers, G;Stringer, B

Title:

Courts' views on climate change inundation risks for developments: Australian perspectives and considerations for valuers

Date:

2020-06-18

Citation:

Cradduck, L., Warren-Myers, G. \& Stringer, B. (2020). Courts' views on climate change inundation risks for developments: Australian perspectives and considerations for valuers. Journal of European Real Estate Research, 13 (3), pp.435-453. https://doi.org/10.1108/ JERER-03-2020-0019.

Persistent Link:

http://hdl.handle.net/11343/251401 